\title{
Heavy Metal Release from Industrial Solid Wastes (Case Study: Khazar Steel Smelting Plant)
}

\author{
Zahra Zamiraei* (D), Mohammad Panahandeh, Habib Fathidokht
}

Environmental Research Institute, Academic Center for Education, Culture \& Research (ACECR), Rasht, Iran

\section{A R T I C L E I N F O}

Received: 23 July 2019

Revised: 13 August 2019

Accepted: 14 September 2019

Available online: 22 September 2019

\section{K E Y W O R D S}

Steel smelting

Waste management

Heavy metals

TCLP test

\begin{abstract}
A B S T R A C T
Information about the heavy metals release from industrial solid wastes is important for more reliable management of their environmental hazards. This study was conducted to investigate the effect of tissue of solid waste on the release of heavy metals from the steel smelting plant. After the investigation at the Khazar steel smelting (KSS) plant in Guilan province, its waste type, source, quantity and quality were characterized. The major wastes generated from the KSS plant were characterized to be the slag, furnace dust, and spent refractories. KSS solid wastes contained heavy metals in varying amounts, with the ranges of 1500-2200, 80-114, 6172-11100, 88-82, 48-29, 56-60, 4-14, 144-370 and 0.9-1.0 mg.kg-1 for $\mathrm{Mn}, \mathrm{Cu}, \mathrm{Zn}, \mathrm{Ni}, \mathrm{Cr}, \mathrm{Co}, \mathrm{Cd}, \mathrm{Pb}$ and $\mathrm{As}$, respectively. The concentration of the iron was high in these wastes (109900-672000 mg.kg-1). The results confirmed the high concentration of heavy metals except for Arsenic. The TCLP results of the KSS dust and slag showed the almost all the heavy metals concentrations by the leaching test were lower than the detection limits except Fe (524.5-187.6 mg.kg-1) and Mn (14-10.10 mg.kg-1). According to the results, all the wastes generated by the KSS plant were reusable and recyclable.
\end{abstract}

G R A P H I C A L A B S T RACT

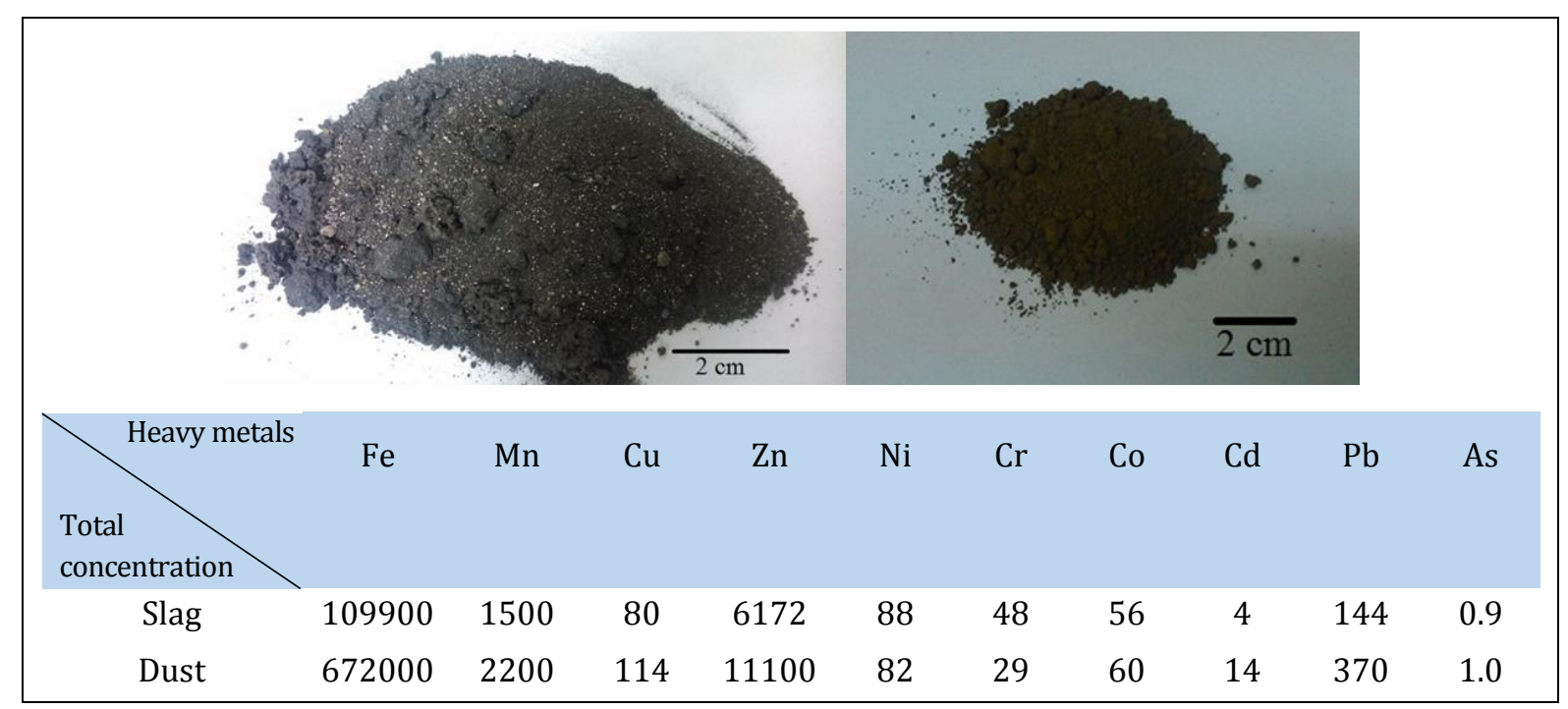

*Corresponding author's E-mail address: Zamiraei@gmail.com 


\section{Introduction}

Rapid development and subsequent industrialization have increased the environmental pollution levels. The number of contaminated sites in industrial areas is increasing in developing countries [1]. Environmental challenges for different industries are associated with liquids, gaseous, and solid wastes [2]. Industrial wastes in solid form have been recognized as one of the major polluting materials, and their management is recognized as an important problem for modern civilization. Unfortunately, industrial solid wastes (ISWs) have been dumped into the land. One of the main problems with ISWs is that they contain high concentrations of heavy metals. The appropriate management should be applied to avoid contamination of soil, water, and plants [3]. Among all the pollutants, heavy metals have received great attention due to their toxic nature. Heavy metals are usually present in trace amounts in natural waters but many of them are toxic even at a very low concentration [4]. Metals such as arsenic, lead, cadmium, nickel, mercury, chromium, cobalt, zinc, and selenium are highly toxic even in minor quantities. Increasing the quantity of the heavy metals in our resources is currently an area of greater concern, especially since a large number of industries are discharging their metal containing effluents into the freshwater without any adequate treatment [5]. Heavy metals become toxic when they are not metabolized by the body and accumulate in the soft tissues. They may enter the human body through food, water, air or absorption through the skin when they come in contact with humans in agriculture, manufacturing, pharmaceutical, industrial, and residential settings [6]. Steel production is defined as the chemical reduction of iron ore or a direct reduction process. Currently, two types of technology are used for steel production, the basic oxygen furnace (BOF) and the electric arc furnace (EAF) [7]. In the oxygen furnace method, steel is produced from the raw iron obtained from a blast furnace with some scrap through pure oxygen. About $67 \%$ of the world's steel was produced by a variety of converters in 2011. In the electric arc furnace method, the steel is produced using scrap and sponge iron obtained by direct reduced iron (DRI) or raw iron obtained from the blast furnace or a combination of the two, by graphite electrodes and applying electric arcs [8]. In 2011, about 31\% of the world's steel was produced by this method [9]. The main input materials of BOF are molten iron, scrap and oxygen. In EAF, electricity and scrap are used as input materials [10]. The BOF method is commonly utilized to produce high-carbon steel, while EAF is used to produce low carbon steel and low-tonnage alloys and special steels [11]. In general, all types of solid waste from the steel industry include coke dust, oxygen furnace slag, steel melting furnace slag, rolling shell, scrap, oil sludge, fly ash, acidic sludge, and refractory materials [12]. Pile of solid waste in open landfill and buried in the ground will cause environmental pollution in the form of dust and leachate along with the financial loading. Besides, the lack of land for solid waste mass has been compounded by the overcrowded population growth [13]. Therefore, the determination of heavy metals in ISWs and the development of a strategy to minimize heavy metals in wastes are important challenges. This study was designed to ascertain the levels of lead $(\mathrm{Pb})$, cadmium (Cd), chromium (Cr), nickel (Ni), zinc $(\mathrm{Zn})$, copper $(\mathrm{Cu})$, cobalt (Co), manganese (Mn), arsenic (As) and iron (Fe) in two types of the Khazar steel smelting (KSS) wastes in Guilan Province and the study of on heavy metal release from these wastes. 


\section{Experimental}

Materials and methods

Study area

The KSS plant is located in the industrial zone of Rasht city in Guilan province, north of Iran. The geographical location of this plan is demonstrated in Figure 1.

- Latitude: $37^{\circ} 10^{\prime} 9^{\prime \prime}$

- Longitude: $49^{\circ} 35^{\prime} 48^{\prime \prime}$

\section{Industrial solid wastes}

Two types of ISW samples were collected from the KSS plant in Guilan Province, Iran. In general, dust and slag were collected from the KSS plant. All the waste samples were passed through a $2 \mathrm{~mm}$ sieve and stored for further analysis. Samples were digested in nitric acid $\left(\mathrm{HNO}_{3}\right)$ and hydrogen peroxide $\left(\mathrm{H}_{2} \mathrm{O}_{2}\right)$ [14], and the total heavy metal concentrations of the digests were measured using a flame atomic absorption spectrometer.

\section{Release of heavy metals from ISWs}

The TCLP is designed to determine the mobility of both organic and inorganic analytes present in liquid, solid, and multiphasic wastes. The samples were crushed to particles less than $10 \mathrm{~mm}$ in diameter. The extraction fluid was transferred to the extraction vessel. The solid phase of the waste was extracted with an amount of extraction fluid equal to 20 times the weight of the solid phase. To prepare the extraction fluid, $5.7 \mathrm{~mL}$ glacial acetic acid $\left(\mathrm{CH}_{3} \mathrm{CH}_{2} \mathrm{OOH}\right)$ diluted with reagent water to a volume of $1 \mathrm{~L}$. The $\mathrm{pH}$ of this fluid was $2.88 \pm 0.05$. The extraction vessel was rotated to make agitation for $18 \pm 2 \mathrm{~h}$ at $30 \mathrm{rpm}$. Then, following the extraction, the liquid extract was separated from the solid phase by filtration. Metals aliquots must be acidified with nitric acid to $\mathrm{pH}<2$ [15]. The amount of the metals in the leachate was determined using the flame atomic absorption spectrometer (FAAS, Buck scientific VGP210).

\section{Result and discussion}

\section{Various units of KSS plant}

The KSS plant produced flats in different dimensions. Various units of this plant include a raw material storage unit (for storing sponge iron, scrap, lime, dolomite and carbon), electric arc furnace (EAF) unit, ladle furnace (LF) and continuous casting unit.

Figure 1. The situation of studied area
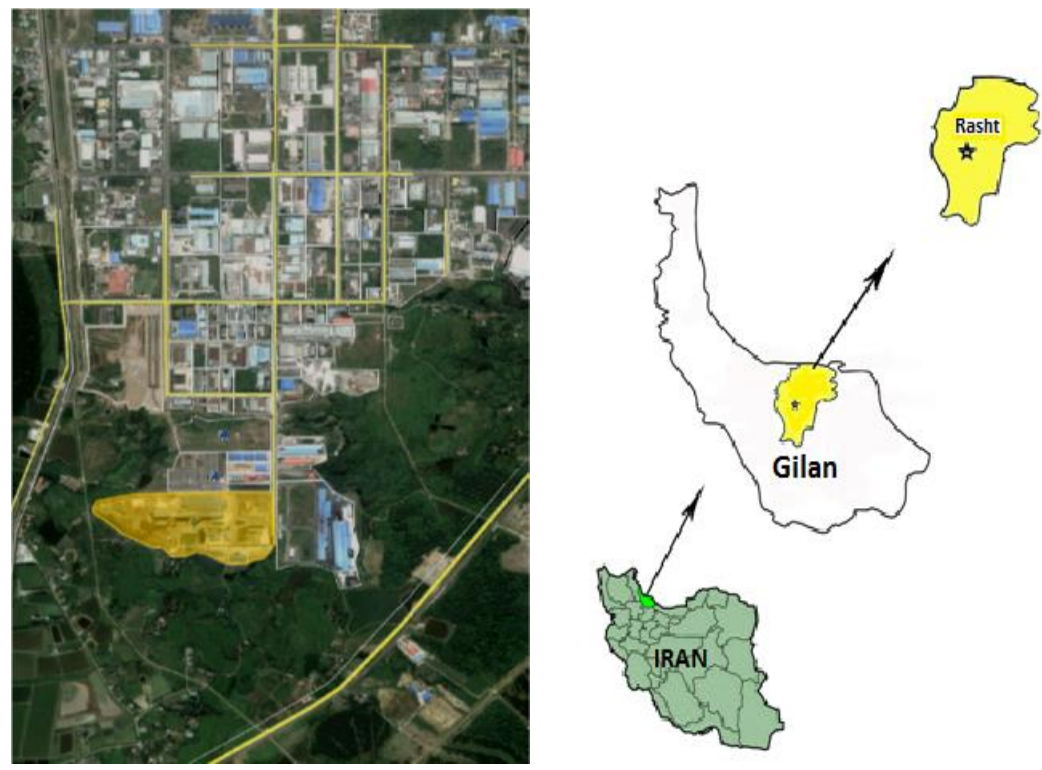


\section{KSS wastes}

The treatment policy of the waste is closely associated with the characteristics of the wastes. It is therefore important to know the physical and chemical properties of the wastes before a treatment method is developed or chosen. The steel fine dust is dark brown, while the gangue slag appears black. The fine dust mostly consists of agglomerated particles that are constituted of oxide, metallic and carbon-based phases, while the gangue slag mainly consists of oxide and carbon-based particles that are irregular in shape.

\section{Slag}

Steel slag, a by-product of steel smelting, is generated during the separation of molten steel from impurities in the steel furnace. The slag is formed during smelting and is a complex compound of silicates and oxides that solidify after cooling. With the production of different grades of steel, the slag properties also change significantly. Slag is usually generated between 200-200 kg per ton of steel, which is predictable for the KSS plant to be between 30-40 thousand tons. Figure 2 demonstrates an example of a slag collected from the KSS plant.

\section{Refractory coatings}

Furnace ages vary in different industries, and the amount of waste from the coating materials depends on the age of the coating, which in turn depends on the quality of the coating materials and the precautions taken in feeding and loading the furnace. Proper thermal insulation of the boilers is carried out using the refractory bricks and insulation materials. The waste from this sample was not available in the KSS plant. The production rate of this type of waste in steel plants is about 2$3 \%$ of steel production, so it is expected to produce about 4-6 thousand tons of refractory bricks in the steel plant annually.

Figure 2. The sample of slag from the KSS plant

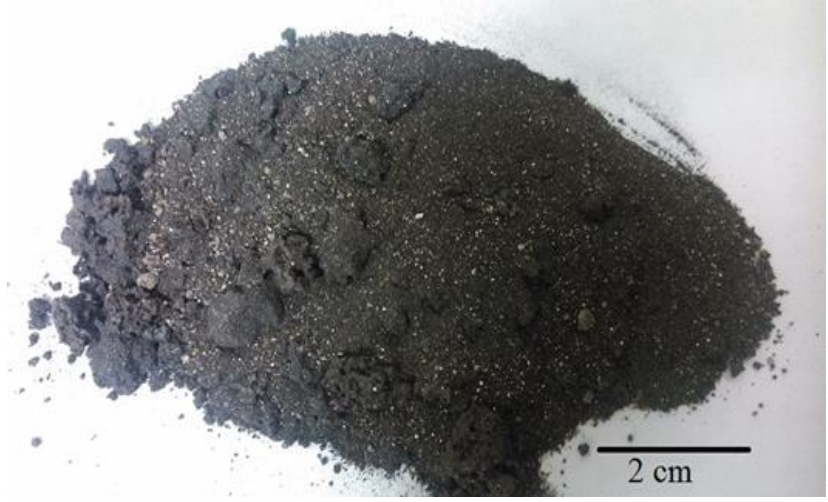

Figure 3. The sample of dust from the KSS plant

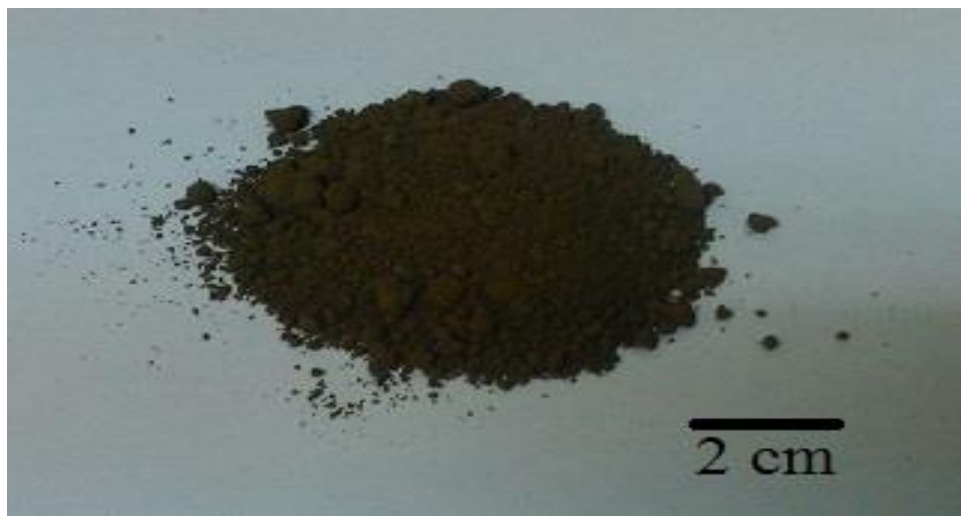


Dust

During the steelmaking process due to high temperatures, iron and other elements present in the melt evaporate and, as getting away from the surface, react with the oxygen present in the media to form solid oxide fine particles, then exit along with outlet gas from the furnace. The hazardous materials of dust released by the EAF are heavy metals such as lead, chromium and cadmium. About 30 to 50 pounds of dust per ton of steel is expected. An annual tonnage of 200,000 tons of steel production of the KSS plant, is expected to produce about 3,000 to 5,000 tons of dust per year. The sample of dust collected from the KSS plant is shown in Figure 3.

Total concentrations of heavy metals in KSS wastes

Total heavy metal concentrations in the KSS sample wastes are presented in Table 1. KSS solid wastes contained heavy metals in varying amounts, with the ranges of 1500 $2200,80-114,6172-11100,88-82$, 48-29, 5660, 4-14, 144-370 and 0.9-1.0 mg.kg-1 for Mn, $\mathrm{Cu}, \mathrm{Zn}, \mathrm{Ni}, \mathrm{Cr}, \mathrm{Co}, \mathrm{Cd}, \mathrm{Pb}$, and As, respectively. The concentration of the iron (Fe) was high in these wastes (109900-672000 mg.kg-1), which is acceptable for the steel industry. The concentration of $\mathrm{Fe}, \mathrm{Mn}, \mathrm{Zn}$ and $\mathrm{Pb}$ in $\mathrm{KSS}$ wastes was relatively high compared with that of the other metals. Based on the results, it is observed that these concentrations of heavy metals are a significant risk for soil and surface water.

\section{Release of heavy metals from KSS wastes}

The release of the heavy metal elements or some other harmful materials from wastes can cause environmental problems such as water and soil pollution, so the leaching toxicity of the wastes was investigated and, toxicity characteristic leaching procedure (TCLP) was adopted. The TCLP results of the KSS dust and slag are presented in Table 2.

Table 1. The total concentration of heavy metals in the KSS wastes (mg.kg-1)

\begin{tabular}{ccccccccccc} 
Heavy metals & $\mathrm{Fe}$ & $\mathrm{Mn}$ & $\mathrm{Cu}$ & $\mathrm{Zn}$ & $\mathrm{Ni}$ & $\mathrm{Cr}$ & $\mathrm{Co}$ & $\mathrm{Cd}$ & $\mathrm{Pb}$ & $\mathrm{As}$ \\
$\begin{array}{l}\text { Total } \\
\text { concentration }\end{array}$ & & & & & & & & & & \\
$\quad$ Slag & 109900 & 1500 & 80 & 6172 & 88 & 48 & 56 & 4 & 144 & 0.9 \\
$\quad$ Dust & 672000 & 2200 & 114 & 11100 & 82 & 29 & 60 & 14 & 370 & 1.0 \\
\hline
\end{tabular}

Table 2. The leachable concentration of heavy metals in the KSS wastes (mg.kg-1)

\begin{tabular}{ccccccccccc} 
Heavy metals & $\mathrm{Fe}$ & $\mathrm{Mn}$ & $\mathrm{Cu}$ & $\mathrm{Zn}$ & $\mathrm{Ni}$ & $\mathrm{Cr}$ & $\mathrm{Co}$ & $\mathrm{Cd}$ & $\mathrm{Pb}$ \\
$\begin{array}{l}\text { Total } \\
\text { concentration }\end{array}$ & & & & & & & & & \\
$\quad$ Slag & 187.6 & 14.0 & 0.017 & 0.54 & 0.068 & Trace & 0.719 & Trace & 0.03 \\
$\quad \begin{array}{c}\text { Dust } \\
\text { Surface water }\end{array}$ & 524.5 & 10.10 & 0.018 & 0.8 & Trace & Trace & Trace & 0.003 & 0.09 \\
$\begin{array}{c}\text { discharge standard } \\
\text { Permissible density } \\
\begin{array}{c}\text { in non-wastewater } \\
\text { shapes (TCLP) [16] }\end{array}\end{array}$ & - & 1 & 1 & 2 & 2 & 1.5 & 1 & 0.1 & 1 \\
\hline
\end{tabular}


As seen in Table 2, almost all the heavy metals by the leaching test were lower than the detection limits except $\mathrm{Fe}$ and $\mathrm{Mn}$ concentrations (524.5 and 10.10 mg.kg-1, respectively, for dust and 187.6 and 14 mg.kg-1 respectively for slag). Iron ( $\mathrm{Fe}$ ) and Manganese (Mn) are metals that exist naturally in soils, rocks and minerals. Therefore, the pollution risks of the heavy metals in the steel slag and dust are very low. So, in most areas, the slags could only treat as the common wastes, not hazardous. In general, dust and slag have no pollution risks for the environment.

\section{Treatment options for KSS wastes}

\section{Refractory wastes}

Refractory wastes are one of the types of solid waste in the consumer industry of refractory products such as steel. The most important step in the recycling process is to sort out and separate the refractory materials to avoid mixing them. Toxic refractories, such as chromium-containing refractories, should be separated from other wastes and buried as hazardous waste in a specific landfill. The non-toxic refractories are then crushed and graded after removing the contaminated parts by special mills $[17,18]$.

\section{Dust}

For optimum utilization of waste, dust was converted to sponge iron using the RHF (Rotary Horizontal Furnace) method. RHF feeds are dust, sludge and oxide shells from steel productions. The input materials convert to pellets or briquettes after mixing with carbon and then through the dryer furnace convert to lump. the strength of the resulting sponge iron (DRI) is about 1.5 times greater than that of the sintered iron ore [19]. Therefore, it is recommended that these wastes be sold to the sponge iron industry.
Slag

The considerable studies have been reported concrete with steel slag has comparable or slightly higher compressive strength, flexural strength, splitting tensile strength and modulus of elasticity, as compared to concrete with normal aggregates [20]. As aggregate in concrete, used in railway infrastructure and soil improvement, it is suggested that steel slag be used as far as possible by selling it to related industries.

\section{Conclusion}

The KSS wastes can be mainly classified into three categories including, refractory wastes, slags, and dust according to the origins and characteristics. The slags and dust were mainly present in the form of complex oxide and silicate and the most important metal elements, such as $\mathrm{Zn}, \mathrm{Pb}, \mathrm{Mn}, \mathrm{Cr}$ and $\mathrm{Ni}$. The slag and dust from the KSS plant are regulated as hazardous wastes as they contain a considerable amount of heavy metals. The leaching toxicity of the KSS slags and dust were investigated, as well. The results obtained from the leaching tests through the TCLP process revealed that the steel dust and slag could be considered as the nonhazardous wastes; however, they might bring some dangers as they contain a high concentration of heavy metal elements. It is suggested that the melting furnace dust is capable of becoming high-quality sponge iron due to its high iron content. The slag can be used as ground filler or as transport infrastructure. Refractory materials can also be recovered in factories after the contaminated parts were removed.

\section{Acknowledgment}

The authors wish to acknowledge the Academic Center for Education, Culture \& Research (ACECR) for its financial support towards the project. 


\section{Disclosure statement}

No potential conflict of interest was reported by the author.

\section{ORCID}

Zahra Zamiraei (iD: 0000-0002-9514-743X

\section{References}

[1] M.D. LaGrega, P.L. Buckingham, J.C. Evans, Hazard waste management, 2nd Ed. McGraw-Hall: New York, 2001.

[2] A.S. Meawad, D.Y. Bojinova, Y.G. Pelovski, Waste Manag., 2010, 30, 2548-2559.

[3] S. Amir, M. Hafidi, G. Merlina, J.C. Revel, Chemosphere, 2005, 59, 801-810.

[4] N. Herawati, I.F. Rivai, H. Koyama, S. Suzuki, Bull. Environ. Contam. Toxicol., 1998, 60, 402-408.

[5] U. Förstner, P. Mader, W. Salomons, Heavy Metals, Problems and Solutions, Springer, 1995.

[6] V. Masindi, K.L. Muedi, Environmental Contamination by Heavy Metals, In Heavy Metal, Intech Open: London, 2018, p 118.

[7] T. Zervas, J.T. McMullan, B.C. Williams, Int. J. energy Res., 1996, 20, 69-91.

[8] Z. Zamiraei, M. Panahandeh, M. Ravanbakhsh, H. Fathi, Res. J. Chem. Environ. Sci., 2016, 4, 62-67.

[9] H. Zhang, H. Wang, X. Zhu, Y.J. Qiu, K. Li, R. Chen, Q. Liao et al., Appl. Energy, 2013, 112, 956-966.
[10] K. He, L. Wang, Renew. Sustain. Energy Rev., 2017, 70, 1022-1039.

[11] G.S. Kumar, D. Basu, Y.T. Hung, L.K. Wang, Waste Treatment in the Iron and Steel Manufacturing Industry, In Waste Treatment in the Metal Manufacturing, Forming, Coating, and Finishing Industries, CRC Press: Florida, 2016, p 38.

[12] E. Metin, A. Eröztürk, C. Neyim, Waste Manag., 2003, 23, 425-432.

[13] D.M. Ceballos, Z. Dong, Environ. Int., 2016, 95, 157-166.

[14] D.E. Kimbrough, J.R. Wakakuwa, Environ. Sci. Technol., 1989, 23, 898-900.

[15] U.S. EPA, Method 1311: Toxicity Characteristic Leaching Procedure, US Environmental Protection Agency: Washington, USA, 1992.

[16] U.S. EPA, Land Disposal Restrictions: Summery of Requirements, U.S. EPA, Land Disposal Restrictions:Summery of Requirements, Offices of Solid Waste and Emergency Response \& Enforcement, EPA 530-R01-007, 2001.

[17] L. Horckmans, P. Nielsen, P. Dierckx, A. Ducastel, Resour. Conserv. Recycl., 2019, 140, 297-304.

[18] A.B. Srinivas, S.K. Sar, S. Singh, S. Yadav, J. Appl. Adv. Res., 2017, 2, 48-55.

[19] A. Chatterjee, Sponge iron production by direct reduction of iron oxide. PHI Learning Pvt. Ltd., 2010.

[20] X. Yu, Z. Tao, T.Y. Song, Z. Pan, Constr. Build. Mater., 2016, 114, 737-746.

How to cite this manuscript: Zahra Zamiraei, Mohammad Panahandeh, Habib Fathidokht, Heavy Metal Release from Industrial Solid Wastes (Case Study: the Khazar Steel Smelting Plant), Adv. J. Chem. A, 2020, 3(3), 336-342. 